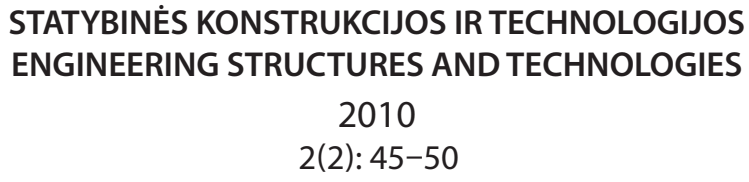

\title{
ADHESIVES IN STRENGTHENING OF STEEL STRUCTURES
}

\author{
Hartmut Pasternak $^{1}$, Gabriel Kubieniec ${ }^{2}$, Marek Piekarczyk ${ }^{3}$ \\ 1,2Brandenburg University of Technology, K.-Wachsmann-Allee 2, 03046 Cottbus, Germany \\ E-mails: ${ }^{1}$ Hartmut.Pasternak@tu-cottbus.de; ${ }^{2}$ kubieniec@tu-cottbus.de \\ ${ }^{3}$ Cracow University of Technology, 24 Warszawska Str., 31-155 Cracow, Poland \\ E-mail:mpiekar@usk.pk.edu.pl
}

Received 2004 2010; accepted 01062010

\begin{abstract}
This study includes a detailed analysis of using adhesives in reinforcement of steel structures. Two types of structures were experimentally investigated: box girder and knee joints. The numerical calculations were done on the basis of the experimental investigations performed at CUT Cracow (box girder) and BTU Cottbus (knee joints) with the use of numerical programme Abaqus based on the Finite Element Method. The numerical results were compared with the experimental ones.
\end{abstract}

Keywords: Adhesives, Box Girder, Knee Joint, Stability, Steel Structures, Strengthening.

\section{Introduction}

Two types of slender structures were chosen for the detailed analysis of an example for using adhesives in reinforcement of steel constructions i.e. knee joint in a frame and a box girder. The experimental investigations conducted at the Brandenburg University of Technology (BTU) Cottbus, Germany in 2006 (knee joint) (Pasternak at. al 2006) and at the Cracow University of Technology (CUT), Poland in 2007 (box girder) (Kubieniec et al. 2008) clearly confirmed that the strengthening method which is based on sticking additional plates to slender webs is effective in both the cases and increases the carrying capacity of the structures to higher degree than other methods of strengthening. On the basis of the experimental results a calibration of a suitable numerical model in qualitative and quantitative aspects was carried out with use of the programme ABAQUS (Hibbit et al. 2001).

\section{State of the art}

Local buckling of slender elements in compression, in particular webs, gives a decisive limitation to the carrying capacity of steel thin-walled girders. Some met- hods of how to prevent girders against local buckling are well known e.g. making additional transverse and/ or longitudinal stiffeners, inserting corrugated sheet for webs or applying stress state opposite to that caused by external loads by pre-tensioning with stiff tube inserts for example. A modern method that may be useful especially in renovation of structures is to apply additional plates glued to the slender elements with adhesives. This method has many advantages. The adhesive connection is characterized by almost uniformly distributed stresses, loading is carried by full contact surfaces in the joint, a rapid stress concentration does not appear in this case and additional initial stresses caused by welding can be avoided. Furthermore, this technique allows to join different types of metals directly that is impossible in other methods because of such problems as bimetallic corrosion in case of joining steel and copper or destroying of a galvanic layer, that is usually associated with leak of toxic gases, in the case of welding zinc-plated steel sheets. Adhesively bonded joints have not been widely used in civil engineering because of many questions like low strength of adhesive in comparison with steel strength, ageing processes causing decrease of carrying capacity of glued joint in 
time or low fire resistance. As the result of rapid development of chemical industry some properties of adhesives have been radically improved and that is why the adhesively bonded joints can be used now wider then in the past.

\section{Tests}

In 2006 at BTU and in 2007 at CUT the experimental investigations of a steel knee joint and box girder respectively strengthened with use of adhesives were carried out. The geometries of the analysed structures are presented in Fig. 1 and Fig. 2. The structures were made of steel S355 (knee joint) and S235 (box girder). The properties of adhesives are presented in Fig 1b. In the case of knee joint seven experiments were carried out. The first one concerned a not reinforced knee joint while the rest of them applied to reinforced knee joints. Each experiment distinguished itself from one another by the number and the thickness of the additional glu- ed plates and by the type of adhesive and the thickness of its layer (cf. Fig. 1c). In every experiment the bending moment $M$ and rotation of internal point of knee joint $\varphi$ were measured. The results of experimental investigations of the knee joints are presented in Fig. 3.

The tests of the box girder enclosed the analysis of the behaviour of the girder strengthened with use of additional plates glued to very slender webs by a two-component epoxy glue. In order to determine the behaviour of the joint consisted of steel-adhesive-steel phases the external load was realized in two cycles with the growths varying from 0 to $300 \mathrm{kN}$. During the third final cycle the load was applied up to the value by which the ultimate carrying capacity was achieved i.e. $500 \mathrm{kN}$. In the second stage of investigations an analysis of the behaviour of a box girder with the same geometrical and material properties as the first one but without reinforcement in the case was carried out (cf. Fig. 2). The carrying capacity of the not strengthened a)

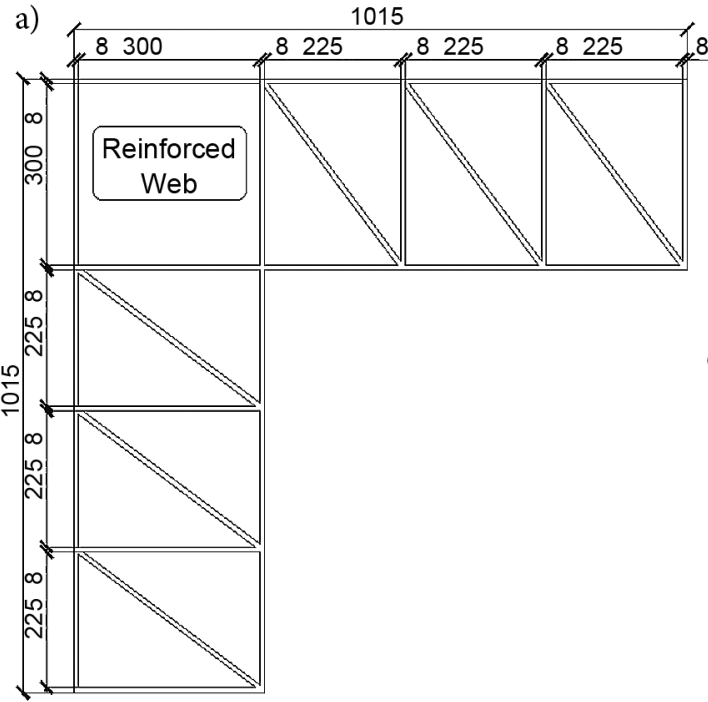

b)
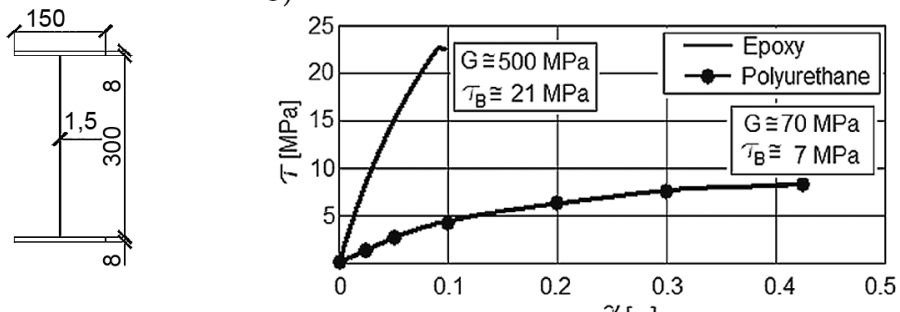

c)

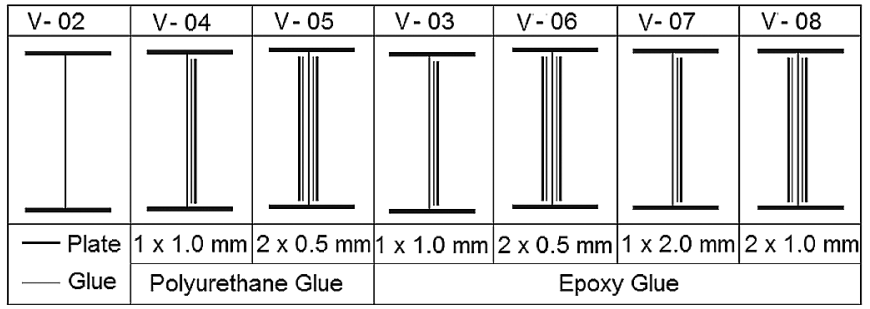

Fig 1. Geometry and layouts of reinforcements of the knee

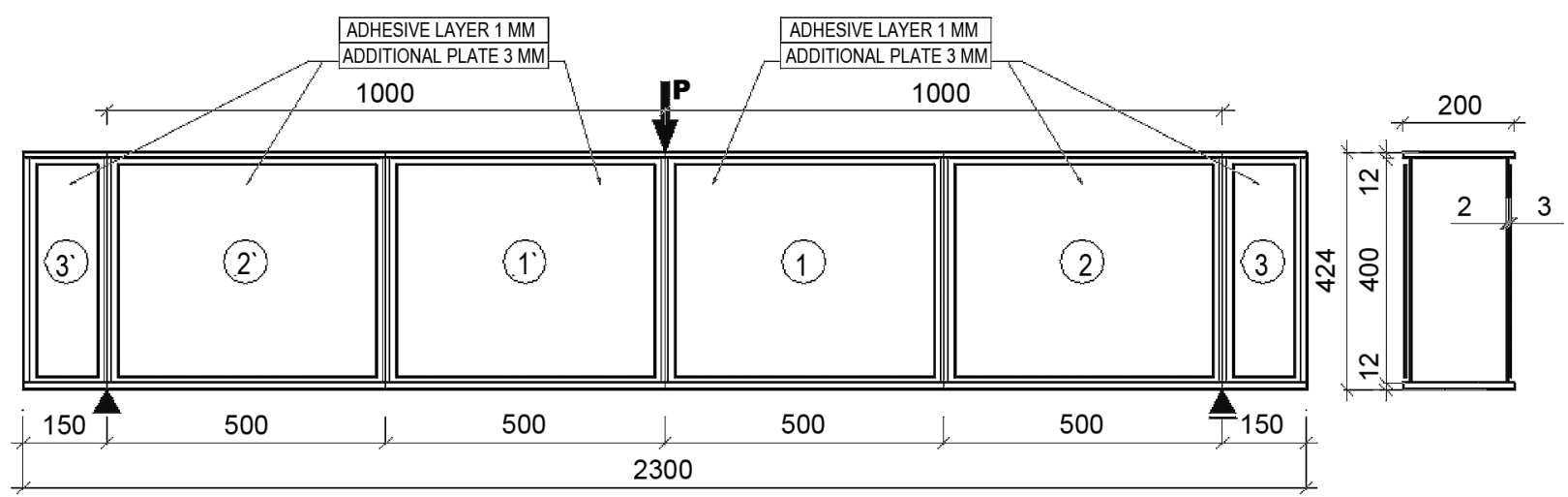

Fig 2. Geometry and layouts of reinforcements of the box girders 

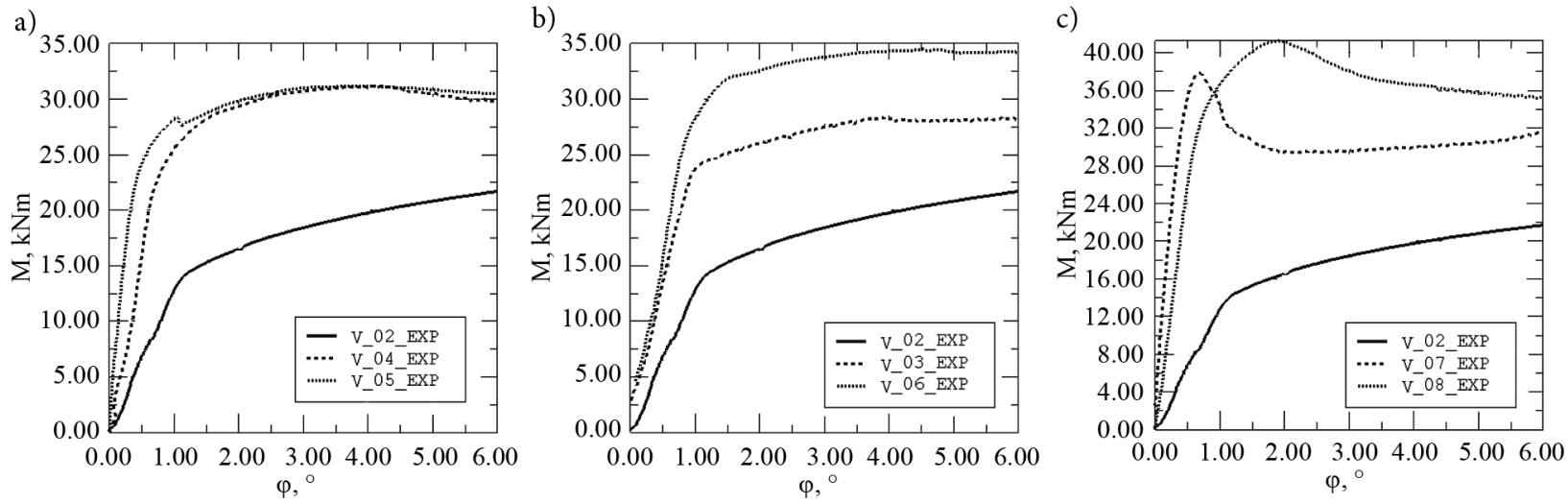

Fig 3. Comparison of experimental $M-\varphi$ diagrams of the reinforced and not reinforced knee joints

girder was $283 \mathrm{kN}$. The value of local buckling load was $145 \mathrm{kN}$. The applied external load $P$ (concentrated force) and deflection $U$ in the middle of the span were measured during the experiments. The results of the experimental investigations for box girders are presented in Fig. 4.

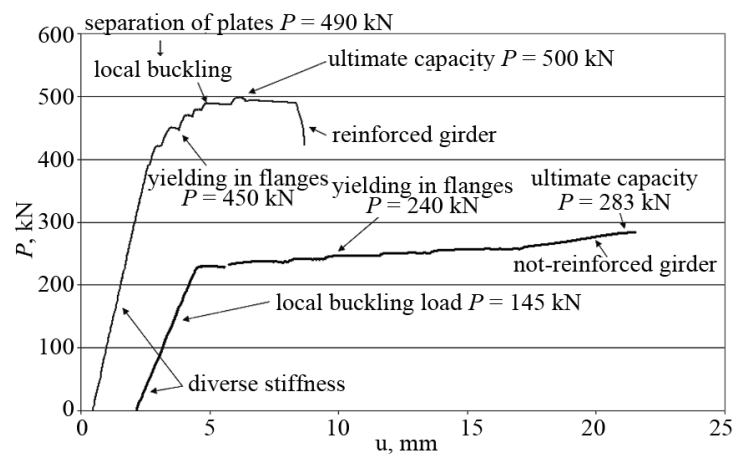

Fig. 4. Comparison of experimental $P-U$ diagrams of the reinforced and not reinforced box girders

\section{Numerical simulations}

The proper numerical calculations were carried out with use of the programme ABAQUS (Hibbit et al. 2001). Calibration of the models was done on the basis of the presented above results of the experimental investigations performed for the knee joints and the box girders. The main structure was modelled with use of the 4 node shell finite elements called S4R. The layer of glue was modelled with use of the 8 node linear brick, hybrid, linear pressure, incompatible modes elements called C3D8IH. The layer of the glue was connected with the main structure by an appropriate definition of contacts based on the theory of so called slave and master surfaces. A specific tie constraint ties two separate surfaces together so that there is no relative motion between them. This type of constraint allows to use toget- her two regions even though the meshes created onthe surfaces of the regions may be dissimilar. It is possible to define a tie constraint between edges of a wire or between faces of a solid or shell. Two different surfaces can be tied together. Each node on the "slave" surface will have the same motion as the point on the "master" surface to which it is closest. An appropriate introduction of geometrical imperfections into the numerical models should have been carefully analysed. The first step of the introduction of imperfections was based on the linear solution of the buckling problem resulting in several local buckling modes. In the second step a linear combination of chosen buckling (local) modes multiplied by adequate factors was created and in this way a new configuration of geometry of the analysed model was achieved. The following assumptions were taken into account during the numerical analysis: the material properties of steel and adhesives estimated on the basis of the tests carried out for the real elements; an elastic-plastic model without reinforcement of steel; an elastic model of the adhesive material; the properties of adhesive like contraction or creep were not considered; material and geometrical nonlinearity; imperfections were introduced into the model; the external load $P$ and deflection $u$ in the middle of the span (box girders) and the bending moment $M$ and the rotation $\varphi$ (knee joint) were measured. The comparison of the numerical and experimental results was done in both the quantitative and qualitative aspects. The statical paths of equilibrium obtained from the numerical and experimental investigations of the knee joints and the reinforced box girder are shown in Fig. 5 and Fig. 6 as well as the qualitative comparison of them in Fig. 7 and Fig. 8 respectively. The distinct conformity of the stiffness of both models and good approximation of the elastic-plastic ranges and the ultimate capacities can be observed. 


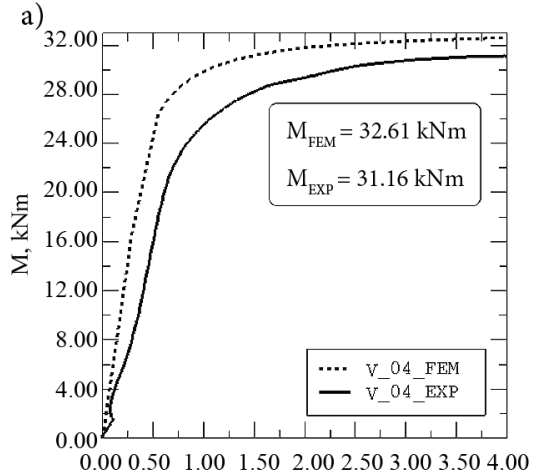

$\varphi$, b)

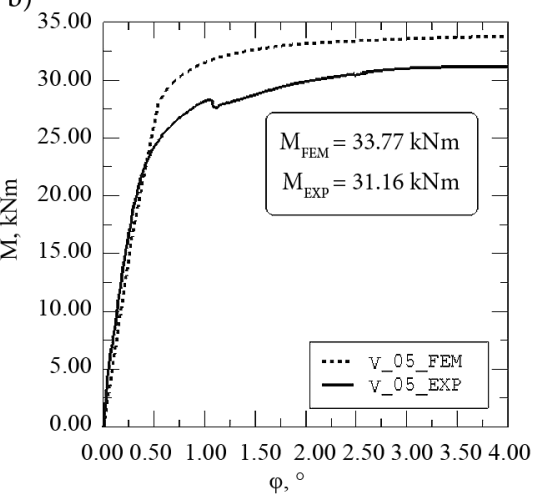

c)

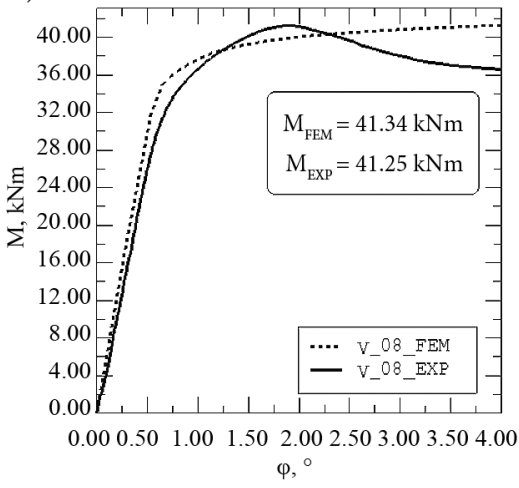

Fig. 5. Comparison of the numerical and experimental $M-\varphi$ diagrams for the knee joints

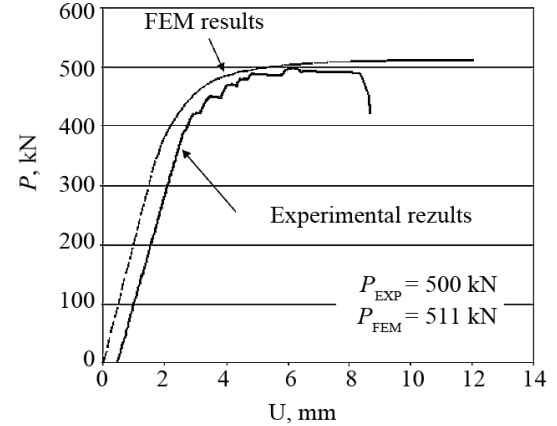

Fig. 6. Comparison of the numerical and experimental $P$ - $u$ diagrams for the reinforced girder
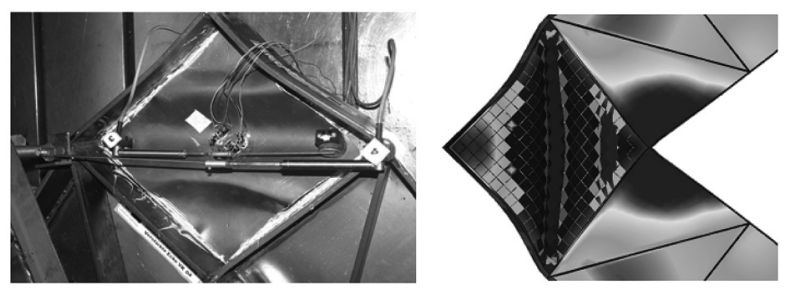

Fig. 7. Qualitative comparison of the numerical and experimental results for the reinforced knee joint
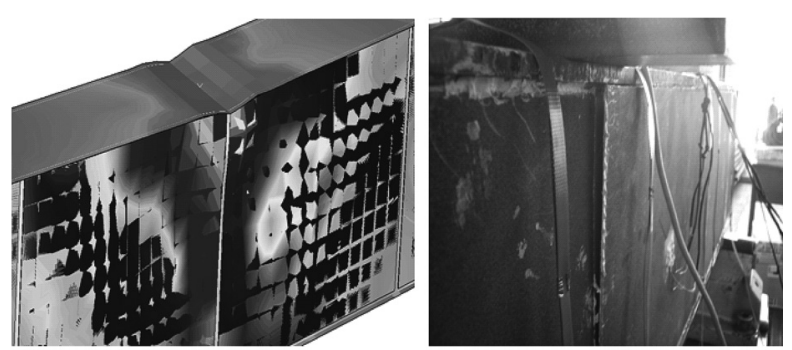

Fig. 8. Qualitative comparison of the numerical and experimental results for the reinforced box girder

\section{Analytical model}

The analytical calculations of the carrying capacity of the reinforced girder were done for the web panel number 1 (Fig. 2) in which the stress state in the layer of adhesive caused by both the bending moment and the shear force was determined. In the case of bending moment and the shear force in the layer of adhesive shear separating stresses appear the direction of which is parallel to the longitudinal axis of the beam for the bending moment and to the depth of beam for the shear force. The stress state caused by the bending moment is described by the equations (1)-(4) an by the shear force by the equations (5)-(9) (Kim et al. 2001). The interaction formula for bending moment and shear force is described by the equation (10) (Kim et al. 2001). The comparison of the analytical and numerical values of stresses are presented in Figures 9-12 respectively:

- bending moment

$$
\tau_{y z}^{a}(x)=t_{o} \lambda_{o}\left[\begin{array}{l}
\frac{\sinh \left(\lambda_{o} y\right)}{\cosh \left(\lambda_{o} c\right)}\left(\frac{N_{y}(x)}{2 t_{o}}-\frac{D_{o}}{\lambda_{o}^{2}}\right)+ \\
\frac{\cosh \left(\lambda_{o} y\right)}{\sinh \left(\lambda_{o} c\right)} \frac{N_{y}(x)}{2 t_{o}}
\end{array}\right]
$$

$$
\lambda=\sqrt{\frac{G_{a}}{t_{a}}\left(\frac{1}{E_{o} t_{o}}+\frac{1}{E_{i} t_{i}}\right)} ;
$$

$D_{o}(x)=\frac{G_{a}}{t_{a}} \frac{N_{y}(x)}{E_{i} t_{i} t_{o}} ;$

$P_{y}(x)=\sigma_{y}^{o}(x) t_{o}$,

$P_{\text {suc }}=1-\left(1-P_{0}\right)^{n}$,

- shear force

$\tau_{x y}^{a}(x, y)=t_{o} \frac{\partial \tau_{x y}^{o}(x, y)}{\partial y}$

$\tau_{x y}^{o}(x, y)=\sum_{m=1 n=1}^{\infty} \sum_{n=1}^{\infty} \frac{\frac{4}{a b} \iint_{00}^{a b} C_{o} \sin \left(\frac{m \pi x}{a}\right) \sin \left(\frac{n \pi y}{b}\right) d y d x}{\left(\frac{\pi m}{a}\right)^{2}+\left(\frac{\pi n}{b}\right)^{2}+\lambda^{2}}$

$\left.\sin \left(\frac{m \pi x}{a}\right) \sin \left(\frac{n \pi y}{b}\right)\right]$ 


$$
\begin{aligned}
& \lambda=\sqrt{\frac{G_{a}}{t_{a}}\left(\frac{1}{G_{o} t_{o}}+\frac{1}{G_{i} t_{i}}\right)} ; \\
& C_{o}(x, y)=\frac{G_{a} N_{x y}(x, y)}{G_{i} t_{a} t_{i} t_{o}} ; \\
& N_{x y}(x)=\tau_{x y}^{i}(x) t_{i} ; \\
& \tau^{a}=\sqrt{\left(\tau_{x z}^{a}\right)^{2}+\left(\tau_{y z}^{a}\right)^{2} \leq \tau_{y}},
\end{aligned}
$$

where $E_{o,} E_{i}, G_{o^{\prime}} G_{i}, t_{o}, t_{i}=$ Young's module, shear module and thickness of additional plate and web respectively, $G_{a}, t_{a}=$ shear module and thickness of adhesive, $c=b / 2$, a, $b=$ length (web length) and width (web depth) of adhesive joint, $N_{y}(x)=$ normal force in web caused by bending moment, $N_{x y}(x, y)=$ shear force in web, $\sigma_{y}{ }^{o}=$ normal stresses in web caused by external load, $\tau_{x y}{ }^{i}=$ shear stresses in web caused by external load, $\tau_{y z}{ }^{a}=$ shear stresses in adhesive layer caused by bending moment, $\tau_{x y}{ }^{a}=$ shear stresses in adhesive layer caused by shear force, $\tau^{a}=$ resultant shear stresses in adhesive layer, $\tau^{y}=$ shear carrying capacity of adhesive layer.

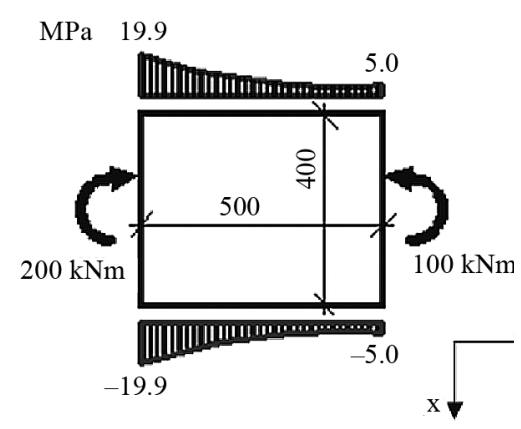

Fig. 9. Shear stresses distribution in web of the reinforced girder caused by bending moment - calculated according to Equations (1)-(4)

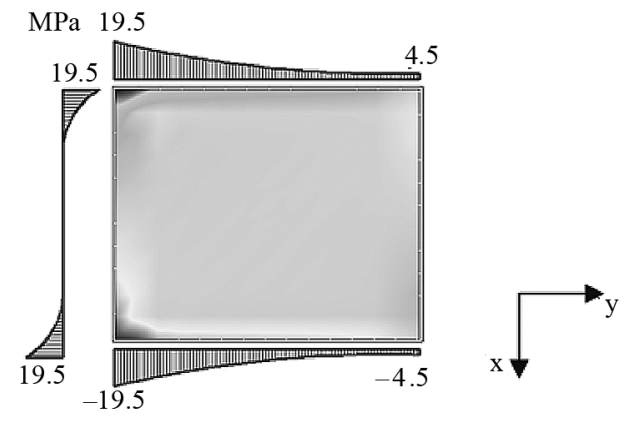

Fig. 10. Shear stresses distribution in the web of reinforced girder caused by bending moment - numerical calculations

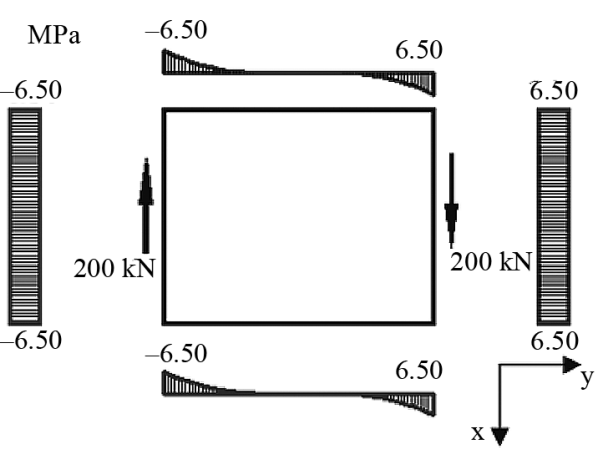

Fig. 11. Shear stresses distribution in the web of reinforced girder caused by shear force - calculated according to equations (5)-(9)

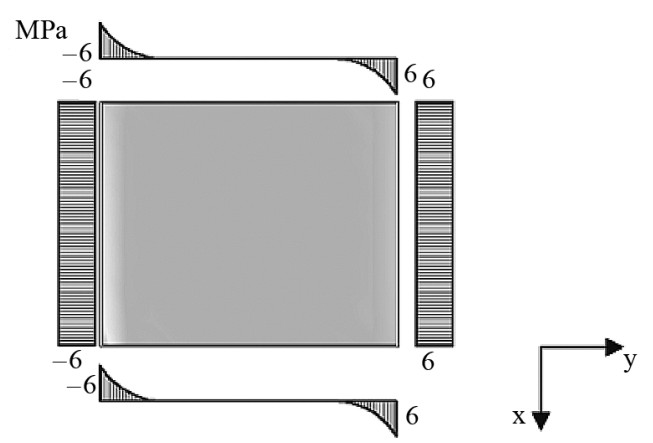

Fig. 12. Shear stresses distribution in the web of reinforced girder caused by shear force - numerical calculation

\section{Conclusions}

The experimental results for the knee joints showed that in the case of epoxy glue the better way of reinforcement is to use two additional plates instead of one plate. A different situation appears in the case of use of polyurethane glue. The increase of the bending moment $M_{a}$ of the reinforced knee joint in comparison with not reinforced one is significant. In the case of experiments V-03 to V-06 the increase varies from $43 \%$ $62 \%$ and for experiments V-07 and V-08 from $151 \%$ to $355 \%$. The additional steel plates glued to the very slender webs of the box girder caused significant increase of its carrying capacity and prevented the webs from local buckling in a large range of loads. During the loading process up to the load $490 \mathrm{kN}$ (separation of plates) the local buckling of the webs did not appear at all and the deformations of the webs were insignificant. At the load $490 \mathrm{kN}$ the failure of adhesive connection of the web panels nearby the applied concentrated force appeared because of exceeding the resistance value of adhesive. The increase of the critical buckling load and carrying capacity in comparison with not reinforced girder amounted $340 \%$ and $60 \%$ respectively. The numerical calculations showed that the analysed gir- 
der and the knee joint may be effectively modelled with use of shell finite elements and the layer of glue by solid finite elements in the FEM technique. The results of analytical calculations of the reinforced girder stay in a good adequacy with the numerical ones and may be used in engineering practice. The resultant stresses in adhesives amount $\tau^{a}=20.9 \mathrm{MPa}$ and are lower then shear resistance of the epoxy adhesive $\tau^{y}=21 \mathrm{MPa}$. In the case of the knee joints the same equations can be used.

\section{References}

Habenicht, G. 2006. Kleben: Grundlagen, Technologien, Anwendung, 5. Auflage Berlin: Springer Verlag.
Hibbit \& Karlsson \& Sorensen, Inc, 2001. Abaqus (standard) Reference Manuals ver. 6 .

Forschung für die Praxis P 654, Neue Konstruktionen durch Einsatz von Klebverbindungen im Stahlbau, FOSTA, Düsseldorf.

Kim, H. \& Kedward, K. 2001. Stress Analysis of In-Plane, ShearLoaded, Adhesively Bonded, Composites Joints and Assemblies, Office of Aviation Research Washington, D.C. 20591, Final Report.

Kubieniec, G. \& Piekarczyk, M. 2008. Thin-Walled Steel Girders Reinforced With Use of Adhesives-Experimental and Numerical Investigation, in Proceedings od The $5^{\text {th }}$ European Conference on Steel and Composites Structures Eurosteel, Graz, 3-5 September 2008, 1611-1616.

Pasternak, H. \& Meinz, J. 2006. Versuche zu geklebten Verstärkungen im Stahlhochbau, Bauingenieur: 81.

\section{KLIJŲ NAUDOJIMAS PLIENINĖMS KONSTRUKCIJOMS STIPRINTI}

\section{H. Pasternak, G.Kubieniec, M. Piekarczyk}

Santrauka. Straipsnyje pateikta analizè, kaip galima sustiprinanti plienines konstrukcijas klijuojant papildomus plieno lakštus. Eksperimentiškai buvo ištirti du konstrukcijų tipai: lenkiamasis dèžinis profilis ir alkūnis elementas, sudarytas iš divitëjo profilio. Remiantis Brandenburgo technologijos universiteto (nagrinèjusio dežzinị profilį) ir Krokuvos technologijos universiteto (nagrinėjusio alkūnį elementą) atliktų eksperimentinių duomenų rezultatais bei taikant baigtinių elementų programą Abacus buvo atlikti ir skaitiniai eksperimentai. Straipsnyje palyginti skaitiniai ir eksperimentiniai rezultatai.

Reikšminiai žodžiai: klijai, dežinis profilis, alkūninis elementas, stabilumas, plieninẻ konstrukcija, stiprinimas.

Hartmut PASTERNAK. Professor, Department of Steel and Timber Construction, Brandenburg University of Technology, Cottbus, Germany. He is involved in teaching, research and design of steel structures for more than 20 years. Under his supervision 8 PhD's were completed. He has several publications in Journals and at Conferences (more than 100) and is coauthor of books in German (4) and English (1) on steel structures. Moreover he is the editor of the journal "Bauingenieur" for steel structures.

Gabriel KUBIENIEC. PhD, Department of Steel and Timber Construction, Brandenburg University of Techno- logy. He got the $\mathrm{PhD}$ in 2009. His research interests include the behaviour of thin-walled steel structures. He has 12 publications in Journals and at Conferences.

Marek PIEKARCZYK. Professor, Department of Steel Structures, Cracow University of Technology, Poland. He is involved in teaching, research and design of steel structures for more than 20 years. Under his supervision $1 \mathrm{PhD}$ was completed. He has several publications in Journals and at Conferences (more than 20) and is co-author of books in Polish on steel structures. 